\title{
Predictive value of serum sodium level in determining perforated appendicitis
}

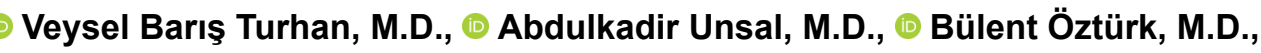 \\ Dogan Ozturk, M.D., Hakan Bulus, M.D.
}

Department of General Surgery, University of Health Sciences, Keçiören Training and Research Hospital, Ankara-Turkey

\begin{abstract}
BACKGROUND: The aim of the study was to investigate the predictive value of hyponatremia as a new biochemical marker for the early and accurate preoperative diagnosis of complicated appendicitis in the adult population.

METHODS: 732 patients who were operated for acute appendicitis (AA) and diagnosed as perforation intraoperatively were evaluated retrospectively. Serum sodium, C-reactive protein (CRP), and leukocyte levels of patients with perforated and nonperforated appendicitis were compared.

RESULTS: Perforated appendicitis patients had statistically lower serum Na values $(p<0.00 \mathrm{I})$. Similarly, patients without perforated appendicitis had higher serum CRP values $(p<0.00 \mathrm{I})$. In patients diagnosed with perforated AA, the sensitivity of plasma sodium concentration was $63 \%$, and the specificity was $66 \%$. The threshold value of plasma sodium concentration $\leq 137.5 \mathrm{mEq} / \mathrm{L}$ had the best possible sensitivity and specificity.
\end{abstract}

CONCLUSION: Hyponatremia is a new marker of perforated appendicitis and therefore, serum sodium level measurement should be considered in patients with a clinical presentation consistent with appendicitis if complications are suspected.

Keywords: Biomarkers; low sodium; perforated appendicitis.

\section{INTRODUCTION}

Acute appendicitis (AA) is the most common cause of emergency abdominal surgery and its lifetime prevalence ranges from 7 to $8 \%{ }^{\left[{ }^{I}\right]}$ Appendectomy is the gold-standard in treatment. Although AA is successfully treated with an early diagnosis and an appropriate approach, perforation may develop in 16-39\% of cases and may lead to life-threatening complications. ${ }^{[2]}$ Perforated appendicitis is 3 times more likely to cause morbidity than simple appendicitis. ${ }^{[2]}$

While it is a historical dogma that AA always progresses towards gangrene and perforation, this is not accepted as right recently. Hence, separating perforated from non-perforated appendicitis may be beneficial for treatment algorithms. ${ }^{[3]}$
Hyponatremia, which is frequently encountered as an electrolyte disorder, is associated with increased morbidity and mortality in the surgical population and is considered as an indicator of prognostic value. ${ }^{[4]}$ Arginine vasopressin concentration is often increased in inflammatory conditions such as acute adult surgery. The underlying pathology is that pro-inflammatory cytokines such as interleukin-I-beta and interleukin-6, which are involved in the severe inflammatory response, increase the secretion of antidiuretic hormone, and cause hyponatremia. ${ }^{[5,6]}$

Recently, hyponatremia has been investigated as a potential diagnostic marker of the presence of complicated appendicitis, as well as a predictive marker of post-operative intra-abdominal complications after treatment for gangrenous (complicated) appendicitis. ${ }^{[7-1 I]}$

Cite this article as: Turhan VB, Unsal A, Öztürk B, Ozturk D, Bulus H. Predictive value of serum sodium level in determining perforated appendicitis. Ulus Travma Acil Cerrahi Derg 2022;28:290-295.

Address for correspondence: Veysel Barış Turhan, M.D.

Sağlık Bilimleri Üniversitesi, Keçiören Eğitim ve Araştırma Hastanesi, Genel Cerrahi Kliniği, Ankara, Turkey

Tel: +90 312 - 3569000 E-mail: drbaristurhan@hotmail.com

Ulus Travma Acil Cerrahi Derg 2022;28(3):290-295 DOI: 10.14744/tjtes.202I.69670 Submitted: 17.07.202I Accepted: 25.09.2021

Copyright 2022 Turkish Association of Trauma and Emergency Surgery 
In our study, the predictive value of plasma sodium concentration in differentiating perforated and non-perforated appendicitis was investigated. Similar studies for adults are very limited. Since it was not a comprehensive study like ours, we hypothesized that plasma sodium concentration might also act as a marker to differentiate between perforated and nonperforated $A A$ in adults.

\section{MATERIALS AND METHODS}

\section{Study Group}

After obtaining institutional ethics committee approval (20I2-KAEK-15/22I7), we performed a retrospective analysis of adult patients (> 8 years) who underwent appendectomy for AA between January I, 2016, and January I, 2020. The criteria for exclusion from the study were: Missing in the file data, under 18 years of age, the final diagnosis was not AA, blood disease, kidney disease, presence of a disease that may affect sodium value, use of medicines that may affect sodium metabolism, detection of malignancy as a result of the pathology, and performing another operation in the same session were excluded from this study. A total of 732 patients who were surgically diagnosed with appendicitis were included in the study.

\section{Study Protocol and Definitions}

Demographic data and laboratory values of the patients were obtained from patient files and computer records. Age, gender, duration of hospital stay, operation time, the number of laparoscopic operations, basal sodium $(\mathrm{Na})$ values, white blood cell (WBC) values, and C-reactive protein (CRP) values of the patients were recorded. In the light of the intraoperative findings, patients diagnosed with perforated appendicitis were selected in the study group, and patients without perforation findings were selected in the control group.

Both groups were compared in terms of $\mathrm{Na}, \mathrm{CRP}$, and WBC levels. All laboratory tests were analyzed in the same labora- tory. The cutoff value, sensitivity, specificity percentages, and significant differences of this parameter in predicting perforated appendicitis were evaluated.

\section{Statistical Analysis}

Statistical analysis was performed with the SPSS program for Windows version 22.0 (SPSS Inc., Chicago, Illinois, USA). Descriptive statistics (mean, SD, median, minimum, and maximum) for numerical variables and frequency distributions for categorical variables were reported. The Student-T test was applied to compare the normally distributed parameters between the two groups. The threshold level for the presence of perforation was determined using the receiver operating characteristic (ROC) test. $\mathrm{P}<0.05$ was considered statistically significant.

\section{RESULTS}

A total of 732 patients who met the study criteria were included in our study. The mean age of these patients was found to be $35.16 \pm 12.86$ years. Of the patients, 427 (58.3\%) were male and 305 (4I.7\%) were female. While the mean of sodium values was $138.1 \mathrm{I} \pm 2.43 \mathrm{mEq} / \mathrm{L}$, the mean of $\mathrm{WBC}$ was found to be $18.13 \pm 17.48 \mathrm{~K} / \mathrm{ml}$. Among them, 65I (88.9\%) had non-perforated appendicitis, whereas 81 ( $11.1 \%$ ) had perforated appendicitis. When the two groups were compared, no statistical difference was found according to age and gender. However, when evaluated in terms of hospital stay, the perforated appendicitis group had a longer hospital stay (Table I).

Hyponatremia (<135 mEq/L) was observed in 37 (5.1\%) of all patients, of which 10 ( $12.4 \%$ of 81 perforated appendicitis patients) were in the perforated appendicitis group, and 27 of them ( $4.2 \%$ of $65 \mathrm{I}$ non-perforated appendicitis patients) were in the non-perforated group (Table I).

Perforated appendicitis patients had statistically lower serum $\mathrm{Na}$ values $(p<0.001)$. Similarly, patients without perforated appendicitis had higher serum CRP values $(p<0.001)$. WBC

Table I. Clinical and laboratory characteristics of patients with acute appendicitis

\begin{tabular}{|c|c|c|c|c|}
\hline & $\begin{array}{c}\text { Total } \\
(n=732)\end{array}$ & $\begin{array}{l}\text { Perforated appendicitis } \\
\qquad(\mathrm{n}=8 \mathrm{I})\end{array}$ & $\begin{array}{l}\text { Non-perforated appendisitis } \\
\qquad(\mathrm{n}=65 \mathrm{I})\end{array}$ & p-value \\
\hline Age (years), Mean $\pm S D$ & $35.16 \pm 12.86$ & $35.86 \pm 9.86$ & $33.16 \pm 11.96$ & 0.32 \\
\hline Male, n (\%) & $427(58.3)$ & $46(56.7)$ & $38 \mid(58.5)$ & 0.3 \\
\hline Operation time, median (minutes) & $35(2|-12|)$ & $36(26-121)$ & $34(21-86)$ & 0.08 \\
\hline Laparoscopic (\%) & $583(79.6)$ & 7I (87.6) & $512(78.6)$ & 0.09 \\
\hline Length of stay, median & $2.1(1-6)$ & $4(3-6)$ & I (I-2) & $<0.001$ \\
\hline \multicolumn{5}{|l|}{ Hyponatremia (<I35 mEq/L), n (\%) } \\
\hline Present & $37(5.1)$ & $10(12.4)$ & $27(4.2)$ & $<0.001$ \\
\hline Absent & 695 (94.9) & 7I (87.6) & $624(95.8)$ & \\
\hline
\end{tabular}

Values that are statistically significant are indicated in bold. SD: Standard deviation. 
Table 2. Comparison of the groups with regard to serum $\mathrm{Na}$ levels, leukocyte counts, and CRP levels

\begin{tabular}{|c|c|c|c|c|}
\hline & Total $(n=732)$ & Perforated $(n=8 I)$ & Non-perforated $(n=651)$ & p-value \\
\hline & Mean $\pm S D$ & Mean $\pm S D$ & Mean $\pm S D$ & \\
\hline Leukocyte, $\mathrm{K} / \mathrm{ml}$ & $15.65 \pm 3,64$ & $|5.5| \pm 3.68$ & $14.54 \pm 3.67$ & 0.451 \\
\hline Serum $\mathrm{Na}(\mathrm{mEq} / \mathrm{L})$ & $138.11 \pm 2.43$ & $136.75 \pm 2.74$ & $138.28 \pm 2.34$ & $<0.001$ \\
\hline CRP (mg/dL) & $2.16 \pm 1.8 .34$ & $2.97 \pm 1.74$ & $2.06 \pm 1.78$ & $<0.001$ \\
\hline
\end{tabular}

Values that are statistically significant are indicated in bold. CRP: C-reactive protein; WBC: White blood cell count; Na: Sodium; SD: Standard deviation. 'Student's t-test.

value had no effect in predicting the diagnosis of perforated appendicitis $(p=0.156)$, (Table 2 ). Logistic regression analysis identified a significant cut-off value and 3 independent predictors (WBC, CRP, and $\mathrm{Na}$ ) for perforated appendicitis, of which hyponatremia was found to have the strongest association with this outcome.

ROC curve and cutoff values for CRP, WBC, and sodium to diagnose perforated appendicitis are given in Figures I-3, respectively.

\section{DISCUSSION}

Appendectomy is known as the gold standard in the treatment of $A A .{ }^{[12]}$ While it is a historical dogma that AA always progresses toward gangrene and perforation, this is not accepted as right recently. ${ }^{[13]}$ Hence, early and accurate detection of perforated appendicitis is significant in patients

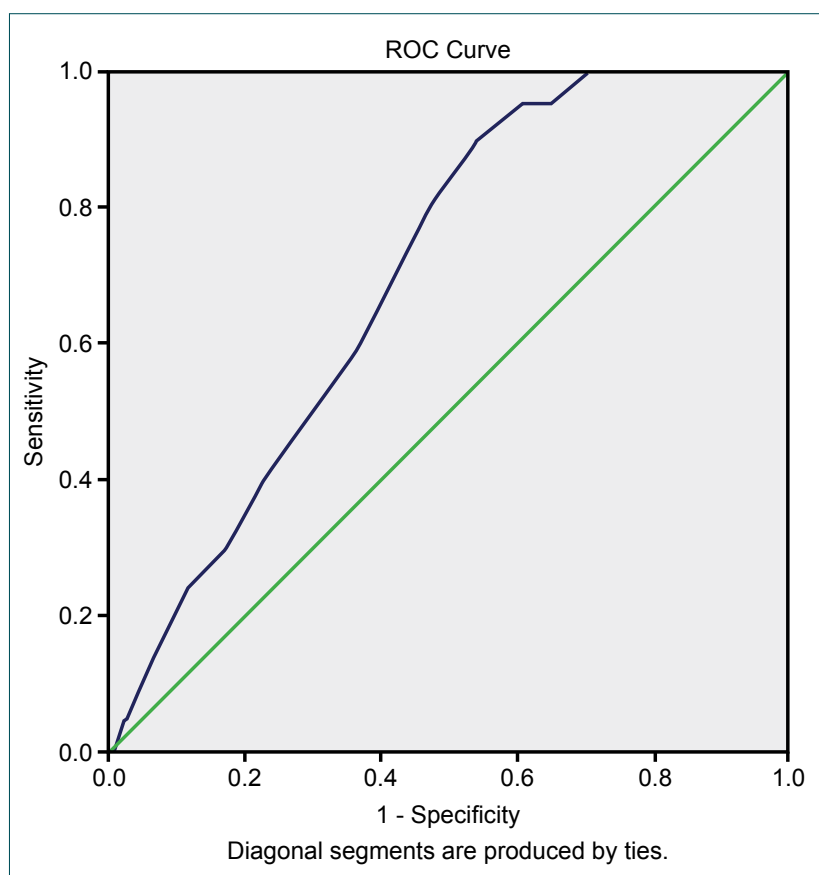

Figure 1. Receiver operating characteristic curves obtained for C-reactive protein (CRP) levels in the diagnosis of complicated appendicitis. AUC: 0.599 (standard error 0.024, p<0.001; 95\% $\mathrm{Cl}=0.651-0.747$ ). The cut-off value for CRP was $\leq 2.35 \mathrm{mg} / \mathrm{dl}$. The sensitivity of this value was $59.3 \%$, and specificity was $63.3 \%$. with $\mathrm{AA}$. In the light of this information, in this study, we investigated the predictive value of basal serum $\mathrm{Na}$ level and inflammatory markers (WBC and CRP) in determining the cases with perforated appendicitis during the follow-up of patients with AA.

There are studies reporting different results and cut-off values on the diagnostic value of inflammatory markers such as leukocytes, neutrophils, and CRP measured from blood. ${ }^{[14-16]}$ In a study conducted by Yang et al. ${ }^{[1]}$ perforated AA, both WBC counts and CRP levels were found to be significantly higher than non-perforated $A A$ in patients with perforated AA. Similarly, Guraya et al. ${ }^{[18]}$ also found significantly higher WBC values in complex (gangrenous, perforated) appendicitis compared to AA. Pham et al. ${ }^{[8]}$ found that WBC $>12.4$ $\mathrm{K} / \mathrm{mL}$ in patients with $\mathrm{AA}$ was an independent predictive marker for perforated appendicitis, whereas Williams et al. ${ }^{[19]}$

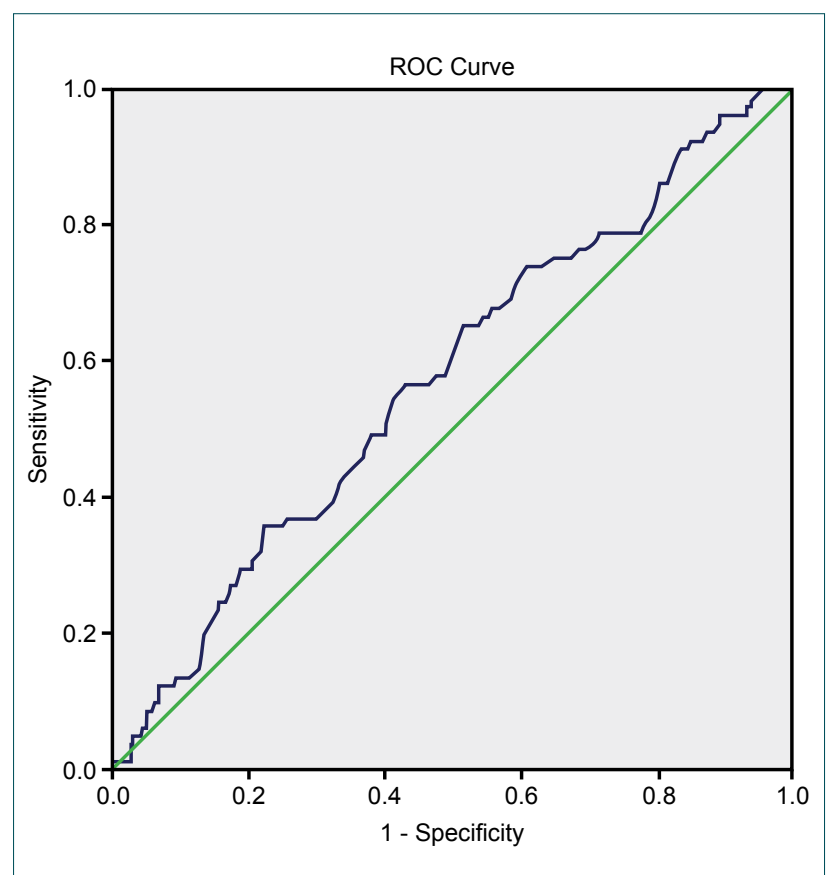

Figure 2. Receiver operating characteristic curves obtained for white blood cell (WBC) levels in the diagnosis of complicated appendicitis. AUC: 0.575 (standard error 0.033, p=0.027; 95\% $\mathrm{Cl}=0.510-0.641$ ). The cutoff value for $\mathrm{WBC}$ was $\leq 14.7 \mathrm{~K} / \mathrm{mL}$, The sensitivity of this value was $56.8 \%$, and specificity was $57 \%$. 


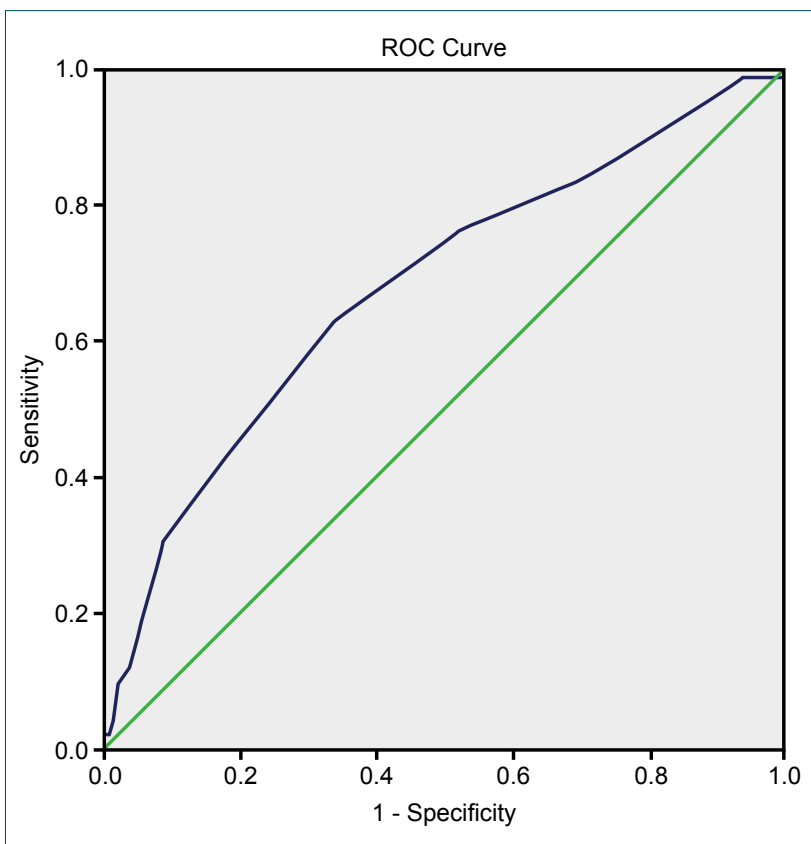

Figure 3. Receiver operating characteristic curves obtained for serum $\mathrm{Na}$ levels in the diagnosis of complicated appendicitis. AUC: 0.678 (standard error $0.03, \mathrm{p}<0.001 ; 95 \% \mathrm{Cl}=0.613-0.743$ ). The cutoff value for serum $\mathrm{Na}$ was $\leq 137.5 \mathrm{mEq} / \mathrm{L}$. The sensitivity of this value was $63 \%$, and specificity was $66 \%$.

found this number $>19.4 \mathrm{~K} / \mathrm{mL}$. Nevertheless, several studies have alleged that WBC counts are insensitive and nonspecific in distinguishing perforated and non-perforated AA. ${ }^{[20-23]}$ In our study, WBC value had no effect in predicting the diagnosis of perforated appendicitis. When the cutoff value was taken as $14.7 \mathrm{~K} / \mathrm{mL}$, the sensitivity and specificity in predicting perforated appendicitis were found to be $56.8 \%$ and $57 \%$, respectively.

In studies on CRP levels, the severity of appendiceal inflammation and high CRP values are correlated. ${ }^{[24]}$ In addition, it was found that CRP may be sensitive in predicting perforated appendicitis. ${ }^{[25]}$ In the study by Dueholm et al., ${ }^{[25]}$ they found that CRP values above $6 \mathrm{mg} / \mathrm{l}$ predicted perforated appendicitis with $75 \%$ sensitivity and $84 \%$ specificity. In a study conducted by Koyuncu and İsmail, ${ }^{[26]}$ the sensitivity and specificity of CRP to differentiate between perforated and nonperforated cases were found to be 0.80 and 0.81 , respectively. In another study, a CRP value greater than $35 \mathrm{mg} / \mathrm{dl}$ had a positive odds ratio of 2.79 to distinguish between acute and perforated appendicitis cases. ${ }^{[27]}$ On the other hand, there are studies showing that CRP has low sensitivity in predicting perforated appendicitis. ${ }^{[28]}$ In another study, it was reported that a high CRP level is a marker with high sensitivity and low specificity in differentiating simple and perforated appendicitis. ${ }^{[22]}$ Besli et al. ${ }^{[1]}$ found CRP level $>2.81 \mathrm{mg} / \mathrm{dL}$ to be a marker with low sensitivity (53.1\%) and mean specificity. In our study, when the perforated and non-perforated groups were compared, CRP values were found to be significantly higher in the perforated appendicitis group, and the sensitiv- ity and specificity values were found to be $59.3 \%$ and $63.3 \%$, respectively, when the cutoff value was taken as $2.35 \mathrm{mg} / \mathrm{dl}$.

The etiology of hyponatremia in patients with perforated AA is unknown; however, it is likely to be an antidiuretic hormone-mediated condition. ${ }^{[9]}$ Although generally hyponatremia has been shown to be associated with complicated appendicitis in the pediatric patient group, ${ }^{[8,10,29]}$ there are some studies showing that it is a predictive marker for cholecystitis and colon perforation in adult patients..$^{[7,30,31]}$ O'Leary et al. ${ }^{[31]}$ found that hyponatremia $(\leq 134 \mathrm{mmol} / \mathrm{L})$ was independently associated with intestinal ischemia, and this finding seems to be related to the etiology of ischemia in perforated appendicitis. In a study evaluating the relationship between hyponatremia and complicated appendicitis in children, it was found that the risk of complicated appendicitis increased 3 times in patients with hyponatremia, and hyponatremia (serum $\mathrm{Na}$ $\leq 135 \mathrm{mEq} / \mathrm{L}$ ) was an independent predictor. ${ }^{[8]}$ However, there are studies that argue the opposite as well. ${ }^{\left[{ }^{\prime \prime}\right]}$ Data on the relationship between perforated appendicitis and hyponatremia in adult patients are very limited. We found three different studies suggesting that hyponatremia may act as a marker in complicated appendicitis during our research. While two of these studies were not significant, one study argued that hyponatremia may be a marker for distinguishing between complicated and uncomplicated appendicitis groups. ${ }^{[7,9,32]} \mathrm{Wu}$ et al. ${ }^{[32]}$ conducted a subgroup analysis of eleven patients in their analysis to investigate hemodialysis patients. Käser et al. ${ }^{[7]}$ in their study, the perforated appendicitis subgroup consisted of 84 patients, and the relationship between hyponatremia ( $\mathrm{Na}$ $<136 \mathrm{mEq} / \mathrm{L}$ ) and perforated appendicitis was not significant. Kim et al. ${ }^{[9]}$ investigated the relationship between hyponatremia $(\mathrm{Na}<135 \mathrm{mEq} / \mathrm{L})$ and intraoperatively defined perforated or gangrenous appendicitis involving 1550 adult patients and stated significant results. In our study, patients with perforated appendicitis had statistically lower serum $\mathrm{Na}$ values.

\section{Conclusion}

Measuring sodium is of definite clinical importance, as it costs much less than measuring CRP or other markers of inflammation, and sodium is often measured in a daily routine. Our study is limited due to its retrospective design and lack of data on the etiology of hyponatremia. In addition, the main purpose of our study is to analyze easily, inexpensively, and routinely available data and to consider serum sodium level measurement in patients with suspected perforation and whose clinical presentation is compatible with AA. We consider that it can be a significant predictive marker if supported by well-designed prospective randomized studies in the future.

Ethics Committee Approval: This study was approved by the Ankara Kecioren Training and Research Hospital Clinical Research Ethics Committee (Date: 09.02.2021, Decision No: 20I2-KAEK-I5/22I7). 
Peer-review: Internally peer-reviewed.

Authorship Contributions: Concept: V.B.T.; Design: V.B.T.; Supervision: V.B.T.; Resource: H.B.; Materials: A.U.; Data: B.Ö.; Analysis: D.O.; Literature search: A.U.; Writing: V.B.T.; Critical revision: H.B.

Conflict of Interest: None declared.

Financial Disclosure: The authors declared that this study has received no financial support.

\section{REFERENCES}

1. Ma K, Chia N, Yeung H, Cheung M. If not appendicitis, then what else can it be? A retrospective review of 1492 appendectomies. Hong Kong Med J. 2010;16:12-7.

2. Gomes CA, Sartelli M, Di Saverio S, Ansaloni L, Catena F, Coccolini F, et al. Acute appendicitis: Proposal of a new comprehensive grading system based on clinical, imaging and laparoscopic findings. World J Emerg Surg 2015;10:1-6. [CrossRef]

3. Blumfield E, Yang D, Grossman J. Scoring system for differentiating perforated and non-perforated pediatric appendicitis. Emerg Radiol 2017;24:547-54. [CrossRef]

4. Leung AA, McAlister FA, Rogers SO, Pazo V, Wright A, Bates DW. Preoperative hyponatremia and perioperative complications. Arch Intern Med 2012;172:1474-81. [CrossRef]

5. Park SJ, Shin JI. Inflammation and hyponatremia: An underrecognized condition? Korean J Pediatr 2013;56:519. [CrossRef]

6. Swart RM, Hoorn EJ, Betjes MG, Zietse R. Hyponatremia and inflammation: The emerging role of interleukin- 6 in osmoregulation. Nephron Physiol 2011;118:45-51. [CrossRef]

7. Käser S, Furler R, Evequoz D, Maurer C. Hyponatremia is a specific marker of perforation in sigmoid diverticulitis or appendicitis in patients older than 50 years. Gastroenterol Res Pract 2013;2013:462891. [CrossRef]

8. Pham XB, Sullins VF, Kim DY, Range B, Kaji AH, de Virgilio CM, et al. Factors predictive of complicated appendicitis in children.J Surg Res 2016;206:62-6. [CrossRef]

9. Kim DY, Nassiri N, de Virgilio C, Ferebee MP, Kaji AH, Hamilton CE, et al. Association between hyponatremia and complicated appendicitis. JAMA Surg 2015;150:911-2. [CrossRef]

10. Lindestam $U$, Almström M, Jacks J, Malmquist P, Lönnqvist PA, Jensen BL, et al. Low plasma sodium concentration predicts perforated acute appendicitis in children: A prospective diagnostic accuracy study. Eur J Pediatr Surg 2020;30:350-6. [CrossRef]

11. Besli GE, Çetin M, Durakbaşa ÇU, Özkanlı Ş. Predictive value of serum sodium level in determining complicated appendicitis risk in children. Haydarpasa Numune Train Res Hosp Med J 2019;59:35-40. [CrossRef]

12. Ruffolo C, Fiorot A, Pagura G, Antoniutti M, Massani M, Caratozzolo E, et al. Acute appendicitis: What is the gold standard of treatment? World J Gastroenterol 2013;19:8799-807. [CrossRef]

13. Coccolini F, Fugazzola P, Sartelli M, Cicuttin E, Sibilla MG, Leandro $\mathrm{G}$, et al. Conservative treatment of acute appendicitis. Acta Biomed 2018;89:119-34.
14. Panagiotopoulou I, Parashar D, Lin R, Antonowicz S, Wells A, Bajwa $\mathrm{F}$, et al. The diagnostic value of white cell count, C-reactive protein and bilirubin in acute appendicitis and its complications. Ann R Coll Surg Engl 2013;95:215-21. [CrossRef]

15. Bedel C. Diagnostic value of basic laboratory parameters for simple and perforated acute appendicitis. Turk J Clin Lab 2018;9:266-71.

16. Rudiman R, Ruchimat T, Ferdinand Y. Diagnostic value of C-reactive protein and neutrophil-limphocyte ratio in perforated appendicitis at Hasan Sadikin Hospital Bandung. Int Surg J 2017;4:3196-200. [CrossRef]

17. Yang J, Liu C, He Y, Cai Z. Laboratory markers in the prediction of acute perforated appendicitis in children. Emerg Med Int 2019;2019:4608053.

18. Guraya SY, Al-Tuwaijri TA, Khairy GA, Murshid KR. Validity of leukocyte count to predict the severity of acute appendicitis. Saudi Med J 2005;26:1945-7.

19. Williams RF, Blakely ML, Fischer PE, Streck CJ, Dassinger MS, Gupta $\mathrm{H}$, et al. Diagnosing ruptured appendicitis preoperatively in pediatric patients. J Am Coll Surg 2009;208:819-25. [CrossRef]

20. van den Broek W, van der Ende E, Bijnen A, Breslau P, Gouma D. Which children could benefit from additional diagnostic tools in case of suspected appendicitis? J Pediatr Surg 2004;39:570-4. [CrossRef]

21. Snyder BK, Hayden SR. Accuracy of leukocyte count in the diagnosis of acute appendicitis. Ann Emerg Med 1999;33:565-74. [CrossRef]

22. Lin CJ, Chen JD, Tiu CM, Chou YH, Chiang JH, Lee CH, et al. Can ruptured appendicitis be detected preoperatively in the ED? Am J Emerg Med 2005;23:60-6. [CrossRef]

23. Nelson DS, Bateman B, Bolte RG. Appendiceal perforation in children diagnosed in a pediatric emergency department. Pediatr Emerg Care 2000;16:233-7. [CrossRef]

24. Eriksson S, Granström L, Carlström A. The diagnostic value of repetitive preoperative analyses of $\mathrm{C}$-reactive protein and total leucocyte count in patients with suspected acute appendicitis. Scand J Gastroenterol .1994;29:1145-9. [CrossRef]

25. Dueholm S, Bagi P, Bud M. Laboratory aid in the diagnosis of acute appendicitis. Dis Colon Rectum 1989;32:855-9. [CrossRef]

26. Koyuncu $\mathrm{S}$, İsmail $\mathrm{O}$. The role of $\mathrm{C}$-reactive protein to lymphocyte ratio in the differentiation of acute and perforated appendicitis. Ulus Travma Acil Cerrahi Derg 2020;26:760-4. [CrossRef]

27. Özozan ÖV, Vural V. High C-reactive protein level as a predictor for appendiceal perforation. Ulus Travma Acil Cerrahi Derg 2020;26:63-6.

28. Beltrán MA, Almonacid J, Vicencio A, Gutiérrez J, Cruces KS, Cumsille MA. Predictive value of white blood cell count and C-reactive protein in children with appendicitis. J Pediatr Surg 2007;42:1208-14. [CrossRef]

29. Pogorelić Z, Lukšić $B$, Ninčević $S$, Lukšić $B$, Polašek $O$. Hyponatremia as a predictor of perforated acute appendicitis in pediatric population: $A$ prospective study. J Pediatr Surg 2020;56:1816-21. [CrossRef]

30. Falor AE, Zobel M, Kaji A, Neville A, De Virgilio C. Admission variables predictive of gangrenous cholecystitis. Am Surg 2012;78:1075-8. [CrossRef]

31. O'Leary MP, Neville AL, Keeley JA, Kim DY, de Virgilio C, Plurad DS. Predictors of ischemic bowel in patients with small bowel obstruction. Am Surg 2016;82:992-4. [CrossRef]

32. Wu HC, Yan MT, Lu KC, Chu P, Lin SH, Yu JC, et al. Clinical manifestations of acute appendicitis in hemodialysis patients. Surg Today 2013;43:977-83. [CrossRef] 


\section{ORİJiNAL ÇALIŞMA - ÖZ}

\section{Perfore apandisit belirlemede serum sodyum düzeyinin öngörü değeri}

\section{Dr. Veysel Barış Turhan, Dr. Abdulkadir Unsal, Dr. Bülent Öztürk, Dr. Dogan Ozturk, Dr. Hakan Bulus}

Sağlık Bilimleri Üniversitesi, Keçiören Eğitim ve Araştırma Hastanesi, Genel Cerrahi Kliniği, Ankara

AMAÇ: Komplike apandisitin erken ve doğru ameliyat öncesi tanısı için yeni bir biyokimyasal belirteç olarak hiponatreminin erişkin popülasyonunda prediktif değerinin araştırılmasıdır.

GEREÇ VE YÖNTEM: Akut apandisit tanısı ile ameliyat edilen ve intraoperatif olarak perforasyon tanısı alan 732 hasta geriye dönük olarak değerlendirildi. Perfore ve perfore olmayan apandisitli hastaların serum sodyum, C-reaktif protein (CRP) ve lökosit değerleri karşılaştırıldı.

BULGULAR: Perfore apandisit hastaları istatistiksel olarak daha düşük serum Na değerlerine sahipti $(p<0.00 \mathrm{I})$. Buna benzer olarak perfore apandisit hastaları olmayanlara göre daha yüksek serum CRP değerlerine sahipti $(p<0.001)$. Perfore akut apandisit tanısı konan hastalarda plazma sodyum konsantrasyonunun duyarlılığı \%63, özgüllüğü \%66 idi. Plazma sodyum konsantrasyonunun $\leq 137.5$ mEq/L eşik değeri, mümkün olan en iyi duyarlılı̆ı ve özgüllüğe sahipti.

TARTIŞMA: Hiponatremi, perfore apandisitin yeni bir belirtecidir ve bu nedenle apandisit ile uyumlu klinik prezentasyonu olan hastalarda komplikasyon şüphesi var ise serum sodyum düzeyi ölçümü dikkate alınmalıdır.

Anahtar sözcükler: Biyobelirteçler; düşük sodyum; perfore apandisit.

Ulus Travma Acil Cerrahi Derg 2022;28(3):290-295 doi: 10.14744/tjtes.2021.69670 